|| ISSN(online): 2589-8698 || ISSN(print): 2589-868X || International Journal of Medical and Biomedical Studies

Available Online at www.ijmbs.info

PubMed (National Library of Medicine ID: 101738825)

Index Copernicus Value 2018: 75.71

\title{
A STUDY ON THE LIPID PROFILE OF HYPERTENSIVE PATIENTS
}

\author{
Pradeep Agarwal ${ }^{1}$, Satish Pandey ${ }^{2}$ \\ 1,2 M D Medicine, Consultant Physician \\ ${ }^{1}$ Pratik Hospital and Research Center Bhilwara \\ ${ }^{2}$ Ram snehi Hospital, Bhilwara
}

Article Info: Received 18 February 2019; Accepted 28 March. 2019

Cite this article as: Agarwal, P., \& Pandey, S. (2019). A STUDY ON THE LIPID PROFILE OF HYPERTENSIVE PATIENTS. International Journal of Medical and Biomedical Studies, 3(4).

DOI: https://doi.org/10.32553/ijmbs.v3i4.180

Address for Correspondence: Satish Pandey, M D Medicine, Consultant Physician

Conflict of interest: No conflict of interest.

\section{Abstract}

Background: Hypertension and dyslipidemia seem to be the two major risk factors contributing to the increasing cardio-vascular disease worldwide including India.

Methods-The present study was carried out on a total of 100 hypertensive patients attending our Hospital and 100 age and sex matched healthy controls. Twelve hour fasting lipid analysis was done for Serum triglycerides (TG), total cholesterol (TC), High Density Lipoprotein (HDL), Low Density Lipoprotein (LDL).

Results: The Mean serum total cholesterol values were highly significant in hypertensive subjects $(231.8 \pm 34.7 \mathrm{mg} / \mathrm{dL})$ as compared to the healthy control subjects $(158.6 \pm 12.10 \mathrm{mg} / \mathrm{dL})$. The mean serum TG level was $107.94 \pm 16.10$ in healthy control subjects, and $214.41 \pm 38.10$ in hypertensive patients. This difference was highly significant. The mean values for HDL $29.82 \pm 6.44$ was $\mathrm{mg} / \mathrm{dL}$ for hypertensive subjects whereas $43.20 \pm 4.41 \mathrm{mg} / \mathrm{dl}$ for healthy control subjects, respectively.

Conclusion: All the lipid profile like cholesterol, LDL, TG and HDL were derange in the hypertensive than those in the healthy controls.

Keywords: Hypertension, Lipid profile, HDL ,TG , LDL.

\section{Introduction:}

Hypertension and dyslipidemia seem to be the two major risk factors contributing to the increasing cardio-vascular disease worldwide including India. As its prevalence is increasing globally, this is of majore concern. The reasons seem to be very many and some associated with unhealthy diet and different life-style. Stress is also a major contributing factor to cardiovascular disease (CVD) but little is known about the mechanisms that underlie this connection ${ }^{1-2}$.
Approximately $25 \%$ of the adult populations are affected. Although historically defined as "an elevation of blood pressure" alone, hypertension is characterized by abnormalities of cardiac output, systemic vascular resistance, and arterial compliance. Essential hypertension has been appropriately called the silent killer because it is usually asymptomatic and undetected. Uncontrolled hypertension can cause damage to all organs of body. ${ }^{3}$

Dyslipidaemia and hypertension are the commonest risk factors for coronary artery 
disease (CAD). Recent reports show that borderline hypertension (systolic BP 130-139 and/or diastolic BP 85-89 $\mathrm{mmHg}$ ) and Stage I hypertension carry a significant cardiovascular risk and there is a need to reduce this blood pressure $^{5}$ The reported prevalence of hypertension varies around the world, with the lowest prevalence in rural India ( $3.4 \%$ in men and $6.8 \%$ in women) and highest in Poland $(68.9 \%$ in men and $72.5 \%$ in women). ${ }^{6}$ It has been found that men have a higher prevalence of hypertension than women although this changes later in life with substantial increase in the number of females with hypertension after the age of 50 years. Dyslipidaemia (hyperlipidaemia), which is associated with hypertension, has been recognised as independent risk factor for cardiovascular disease, a leading diagnosis for visits to physicians and cause of death. ${ }^{7,8}$

\section{MATERIALS AND METHODS}

Patients who diagnosed as cases of essential hypertension based on history and on Antihypertensive Medication were included. The selected subjects were further grouped as:

GROUP 1: Healthy control subjects $(n=100)$. It was ensured by routine examination that all the subjects were healthy and there were no signs and symptoms of hypertensive and other disease.

GROUP 2: Hypertensive subjects $(n=100)$. It included the clinically established patients of hypertension. There blood pressure is in range of systolic blood pressure (>140 $\mathrm{mmHg}$ ) and diastolic blood pressure $(>90 \mathrm{mmHg})$ and have no symptoms of diabetes mellitus.

An informed consent was taken from all the healthy control subjects and patients, under study apprising them the nature and objective of the study. All subjects were studied as outpatient. Participant's examination included interviews for medical and nutritional history. Present and past history of each case was recorded in detail regarding their general information i.e. name, age, sex, address, religion, occupation, economic status, nutritional and personal habits, education, medication and history suggestive of any systemic illness. Each subject was then examined for various anthropometric parameters: Weight (Kg), height (meters),BMI(Body Mass Index ) was calculated by Weight (Kg) / height squared (m2) and Blood pressure (BP).

After on overnight fast of 10-12 hours, fasting blood samples were collected .Blood samples were drawn from anticubital vein of each subject by using aseptic technique. The blood was collected in plain tubes for lipid parameters respectively. Serum was separated after centrifugation and analysed.

\section{RESULTS:}

Table 1: Socio-demographic variable

\begin{tabular}{|l|l|l|l|}
\hline Socio-demographic variable & GROUP-1 & GROUP-2 & P-value \\
\hline Age & $45.13 \pm 7.65$ & $45.80 \pm 8.23$ & $>0.05$ \\
\hline M:F & $61: 39$ & $65: 35$ & $>0.05$ \\
\hline BMI & $22.64 \pm 1.82$ & $23.10 \pm 2.04$ & $>0.05$ \\
\hline
\end{tabular}

Socio-demographic variable between both groups were comparable.

Table 2: Blood pressure

\begin{tabular}{|l|l|l|l|}
\hline BP & GROUP-1 & GROUP-2 & P-value \\
\hline SBP & $116.4 \pm 4.32$ & $142.8 \pm 4.42$ & $<0.05$ \\
\hline DBP & $75.10 \pm 4.12$ & $102.8 \pm 3.86$ & $<0.05$ \\
\hline
\end{tabular}


The mean systolic blood pressure of the healthy controls and hypertensive subjects in the present study was $116.4 \pm 4.32$ and $142.8 \pm 4.42 \mathrm{mmHg}$. The mean diastolic blood pressure of the healthy controls and hypertensive subjects in the present study was $75.10 \pm 4.12$ and $102.8 \pm 3.86 \mathrm{mmHg}$ respectively.

Table 3: Lipid profile

\begin{tabular}{|l|l|l|l|}
\hline Lipid profile & GROUP-1 & GROUP-2 & P-value \\
\hline TC $(\mathrm{mg} / \mathrm{dl})$ & $158.6 \pm 12.10$ & $231.8 \pm 34.7$ & $<0.001$ \\
\hline LDL $(\mathrm{mg} / \mathrm{dl})$ & $95.50 \pm 15.66$ & $158.10 \pm 32.10$ & $<0.001$ \\
\hline HDL $(\mathrm{mg} / \mathrm{dl})$ & $43.20 \pm 4.41$ & $29.82 \pm 6.44$ & $<0.001$ \\
\hline TG $(\mathrm{mg} / \mathrm{dl})$ & $107.94 \pm 16.10$ & $214.41 \pm 38.10$ & $<0.001$ \\
\hline
\end{tabular}

The Mean serum total cholesterol values were highly significant in hypertensive subjects $(231.8 \pm 34.7 \mathrm{mg} / \mathrm{dL})$ as compared to the healthy control subjects $(158.6 \pm 12.10 \mathrm{mg} / \mathrm{dL})$. The mean serum TG level was $107.94 \pm 16.10$ in healthy control subjects, and $214.41 \pm 38.10$ in hypertensive patients. This difference was highly significant. The mean values for HDL 29.82 \pm 6.44 was $\mathrm{mg} / \mathrm{dL}$ for hypertensive subjects whereas $43.20 \pm 4.41 \mathrm{mg} / \mathrm{dl}$ for healthy control subjects, respectively.

\section{Discussion:}

The Mean serum total cholesterol values were highly significant in hypertensive subjects $(231.8 \pm 34.7 \mathrm{mg} / \mathrm{dL})$ as compared to the healthy control subjects $(158.6 \pm 12.10 \mathrm{mg} / \mathrm{dL})$. The mean serum TG level was $107.94 \pm 16.10$ in healthy control subjects, and $214.41 \pm 38.10$ in hypertensive patients. This difference was highly significant. The mean values for HDL 29.82 \pm 6.44 was $\mathrm{mg} / \mathrm{dL}$ for hypertensive subjects whereas $43.20 \pm 4.41 \mathrm{mg} / \mathrm{dl}$ for healthy control subjects, respectively in our study.

The significantly higher plasma total cholesterol, triglycerides and LDL-cholesterol in the hypertensive than in the normotensive patients in the present study is in corroboration with earlier studies. ${ }^{9-12}$

In accordance to our study, Saha MS et al (2006) also reported a statistically highly significant relation in serum TG level in hypertensive subjects $(184.77 \pm 5.97 \mathrm{mg} / \mathrm{dL})$ as compared to the healthy controls $(142.73 \pm 6.68 \mathrm{mg} / \mathrm{dL}) .^{13}$
Kumar NL et al (2010) reported a statistically highly significant relation in serum TG level in hypertensive subjects $(180.88 \pm 68.5 \mathrm{mg} / \mathrm{dL})$ as compared to the healthy controls $(114.7 \pm 17.62$ $\mathrm{mg} / \mathrm{dL}){ }^{14}$

\section{CONCLUSION:}

All the lipid profile like cholesterol, LDL, TG and HDL were derange in the hypertensive than those in the healthy controls.

\section{REFERENCES:}

1. WHO. World Health OrganisationInternational Society of Hypertension Guideline for the management of hypertension (Guideline Sub-Committee). J Hypertens 1999; 151-183.

2. The sixth Reports of the Joint National Committee on Detection, Evaluation and Treatment of High Blood Pressure (JNC VI). Arch Intern Med 1997; 157: 2413-2446.

3. WHO. Classification of hypertension. Report of WHO Scientific Group, Technical Report Series 1978; 657: 87-95.

4. Gupta R: trends in hypertension epidemiology in india. J Hum Hypertens. 2004; 18:73-78.

5. Kearney $P$ M whelton $M$, Reynold $K$, Whelton $\mathrm{Pk}, \mathrm{H} \mathrm{J}$, Worldwide prevalence of hypertension: a systematic review. J Hypertens. 2004 Jan; 22(1):11-9.

6. Gordon H. hypertensive vascular disease. In: Eugene Braunwald et. al. (ed). Harrison's Principles of Internal Medicine 15th edition. McGraw-New York 2000; Pp 141-1430. 
7. Kadiri S. Current concepts in the management of hypertension. Dokita 1999; 26: 93-96.

8. Shahid A, Zuberi SJ, Hasnain N. Lipid pattern in healthy subjects. Pak J Med Res 1985; 24: 33-7.

9. Youmbissi TJ, Djoumessi S, Nouedoui C. Profile lipidique d'un group d'hypertendus camerounais noir Africains. Medicine d'Afrique Noire 2001; 31: 114-118.

10. Ahaneku JE, Nwosu MC, Ahaneku GI, Okugba PC. Utilisation of Clinical chemistry tests with special reference to lipid profile in disease management in a Nigeria setting. East Afr Med J 1999; 76:172-175.

11. Mgonda $Y M$, Ramaiya $K L$, Swai $A B M, M c-$ Larty DG, George KM, Alberti M. Insulin resistance and hypertension in non-obese Africans in Tanzania. Hypertension 1998; 31: 114-118.

12. Jarikre $A E$, Dim DC, Ajuluchukwu JNA. Plasma lipid levels in Nigerian hypertensives: the gender factor. Nig Qtr J Hosp Med 1996; 6: 293-298.

13. Saha MS, Sana NK and Ranajit Kumar Shaha, Serum lipid profile of hypertensive patients in the northern region of the Bangladesh..J. Bio-Sci; 2006;14: 93-98.

14. Kumar NL, Deepthi J, Rao YN, Deedi MK, Study of lipid profile, serum magnesium and blood glucose in hypertension. Biology and Medicine; 2010; 2(1): 6-16. 